\title{
The reconstruction of easterly wind directions for the Eifel region (Central Europe) during the period 40.3-12.9 ka BP
}

\author{
S. Dietrich and K. Seelos \\ Institute for Geosciences, Johannes Gutenberg-University, J. J. Becherweg 21, 55099 Mainz, Germany
}

Received: 26 August 2009 - Published in Clim. Past Discuss.: 22 September 2009

Revised: 17 March 2010 - Accepted: 18 March 2010 - Published: 23 March 2010

\begin{abstract}
A high resolution continuous reconstruction of last glacial wind directions is based on provenance analysis of eolian sediments in a sediment core from the Dehner dry Maar in the Eifel region (Germany). This Maar is suitable to archive easterly wind directions due to its location west of the Devonian carbonate basins of the Eifel-North-SouthZone. Thus, eolian sediments with high clastic carbonate content can be interpreted as an east wind signal. The detection of such east wind sediments is applied by a new module of the RADIUS grain size analyze technique. The investigated time period from $40.3-12.9 \mathrm{ka}$ BP can be subclassified in three units: The first unit covers the periods of the ending GIS-9, H4, and GIS-8. With the exception of H4 (40$38 \mathrm{ka} \mathrm{BP})$ the content of organics in our record is relatively high. With the end of GIS-8 (38-36.5 ka) the content of organics decrease and the content of dust increases rapidly. The second time slice (36-24 ka BP) has an increased content of dust accumulation and a high amount of east winds layers (up to $19 \%$ of the dust storms per century came from the east). In comparison, the subsequent period (24-12.9 ka BP) is characterized by lower east wind sediments again. Increased frequencies of east wind occur during the time intervals corresponding with the Heinrich events $\mathrm{H} 1$ and $\mathrm{H} 2$. The unusual H3 show no higher east wind frequency but so do its former and subsequent Greenland stadials. The late LGM (21$18 \mathrm{kaBP}$ ) is characterized by a slightly elevated east wind frequency again.
\end{abstract}

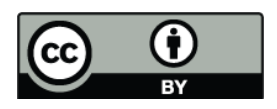

Correspondence to: S. Dietrich (sdietrich@uni-mainz.de)

\section{Introduction}

The climate situation in Central Europe during the Last Glacial Maximum (LGM) and the Late Pleniglacial is characterized by high wind activity and relatively low precipitation (Huijzer and Vandenberghe, 1998; Hatté et al., 1998). This conclusion is based on a comparison of proxy data and climate simulations. The methods of generating proxy data contain relict dune forms in Central Belgium (Vandenberghe, 1991) and Poland (Godzik, 1991), grain size trends of cover sand and loess in the Netherlands (van Huissteden et al., 2001), provenance analyses by heavy mineral composition (Krook, 1993) and wind polished rock surfaces (Christiansen, 2004; Christiansen and Svensson, 1998; Vandenberghe et al., 1999). The balancing of these data with climate model results allows wind direction reconstruction for Central Europe for the LGM and the Late Pleniglacial (Renssen et al., 2007). This combination of meteorological simulations and proxy data shows that the Late Pleniglacial and the LGM were dominated by westerly to north westerly wind directions due to the location of the study area in the mid latitudes. The same situation is postulated for the Younger Dryas (YD), the so called Heinrich-0 event (Isarin et al., 1997). Brauer et al. (2008) have shown an abrupt increase in the strength of the westerlies during the YD at the Meerfelder Maar in the Eifel region. Both models confirm the possibility of a higher number of east winds during the modeled periods. Another simulation reconstructs the atmospheric circulation over the North Atlantic and Eurasia during Heinrich2 (Hostetler et al., 1999). This model separates the H2 in three different phases of climate conditions. Variables are the thickness of the Laurentide ice sheet (LIS) and the Sea Surface Temperature (SST) in the North Atlantic. According to Hostetler et al. (1999) the second phase, a combination of a lowered ice sheet thickness and an increased post-surge SST during the winter simulation, shows a high pressure cell over

Published by Copernicus Publications on behalf of the European Geosciences Union. 
Europe, which implies a higher concentration of north-east winds. During the third phase, with an increasing LIS thickness and decreasing SST, the high pressure cell over Europe becomes stronger again.

All presented proxy data mirror the paleo wind directions during Marine Isotope Stage (MIS) 2 very well. The question is if they are qualified to be the basis for simulations on a very high temporal resolution. Regarding the data, the main disadvantage of using sand dune orientations for wind direction reconstructions is the fact that only the last phases of deposition are represented on top of the dune. Otherwise, wind polished rocks represent the main wind direction over a long period, but hide the variations of wind direction in time. The analyses of grain size trends over a transect of dunes carry information about the paleo wind direction and sometimes also about the wind strength. But these techniques assume free transport paths over the surface without disturbing topographic barriers (Schwan, 1988). Provenance analyses by heavy minerals or other index materials are very useful, if the potential sources of sediment are well known and the distance to the deposition areas is not too far. Mostly the river sediments that cross the northern part of Central Europe show typical fingerprints and can be used for wind direction reconstructions.

In addition to the availability of adequate proxy data, the question about the quality of climate models concerning their resolution in space and time must be discussed. Small scale variances of topography and vegetations are not reproduced by low resolution atmospheric simulations. For example the ECHAM wind direction simulation for the Late Pleniglacial and the LGM (Renssen et al., 2007) has a horizontal resolution of $2.8^{\circ}$. This means, that the complete area of Denmark is represented by only one seawater grid cell, but for the Netherlands and Poland the model allocates land cells. Because of the different physical parameters of land and sea cells, the model results for Denmark, the Netherlands and Poland are not comparable to each other. A slightly higher horizontal resolution of $2^{\circ}$ is given by the GENESIS AGCM simulations of the atmospheric circulation during Heinrich 2 (Hostetler et al., 1999). The most current modeling approach is done by Sima et al. (2009) with the LMDZ atmospheric circulation model (spatial resolution $60 \mathrm{~km}$ ). Model results from this dust emission model show a proportional increase of east wind during Heinrich events in comparison to Greenland Stadial (GS) or Greenland Interstadial (GIS) periods.

In this study we will show a continuous record of changing wind directions during the Late Weicheslian. Because of the complexity of time transient atmospheric simulations, it would be helpful for climate modelers to get high resolution and continuous data of paleo east wind proxies to find interesting time slices for simulations. Such data could be uses in future specific simulation runs.

\section{Methods}

The sediment core De3 for this study comes from the Dehner Maar, which lies in the northwest of the western Eifel volcanic field (WEVF), north of the town of Reuth (Germany). De3 is part of the ELSA (Eifel Laminated Sediment Archive) dust stack (Seelos et al., 2009). The dry maar is located on the west side of a large carbonate basin that crosses the region in north-south direction (Fig. 1). There are no carbonate sources in the nearer western region of the Dehner Maar. The nearest carbonate source to the West of Dehner Maar are cretaceous units near Liège or Aachen, which lie over $60 \mathrm{~km}$ to the NW. The nearest lime stone units are Triassic outcrops in the Meuse valley ( $130 \mathrm{~km}$ to the west). All other maar lakes, which are part of the ELSA project are located in side or at the east side of the basin. Although it silted up approximately 12000 years ago, the maar is still recognizable in the landscape. It has a diameter of $950 \mathrm{~m}$ and lies at an elevation of $565 \mathrm{~m}$ a.s.l. at the crest of a hill. The maar basin is round and does not display any recognizable inflow in the past, but there is an outflow to the south. Thus, the Dehner Maar fulfill the morphological requirement for being suitable to conserve storm sediment layers (Pfahl et al., 2009).

Our east wind dataset depends on provenance analyses of wind transported carbonates. The continuous record is $39 \mathrm{~m}$ long, spans over the time 40.3-12.9 ka BP and has a sample interval of $500 \mu \mathrm{m}$. Beneath the high resolution and the totality of the record, the particle detection algorithm of RADIUS (Seelos and Sirocko, 2005) allows the measurement of single particle diameters.

\subsection{Lithology and stratigraphy of the core De3}

The De3 core consists in all fine-grained sections a reddish tone and sections with a yellow tone, which are always composed of silt-sized dust particles that was blown in from the greater surroundings. The core photograph (Fig. 5) shows these two dominant colors, thus the yellow, loess-rich defining cold periods, the red tone-rich warm periods. The black colored sections are composed of singular, dm-thick volcanic ash layers. The upper most three meters are composed of solifluction debris.

The age model for the core De3 is based on ${ }^{14} \mathrm{C}$-dating, tephrachronology and tuning to the ss09sea stratigraphy of the NGRIP ice core (NorthGRIP Members, 2004). The stratigraphy is supported by six ${ }^{14} \mathrm{C}$ samples as well as geochemical evidence for the Laacher See Tephra (LST) at $3.49 \mathrm{~m}$ depth, which gives an age of $12.9 \mathrm{ka} \mathrm{BP}$ (van den Bogaard, 1995) and is published by Seelos et al. (2009).

The $39 \mathrm{~m}$ long core sequence $(3-42 \mathrm{~m}$ depth) represents a period from 40.3 to $12.9 \mathrm{ka} \mathrm{BP}$, and thus covers the late MIS 3, the transition into the MIS 2, the Late Pleniglacial, and Bølling/Allerød. The core sequence is event laminated and there is no evidence for a hiatus, with exception of a slide between $37-36 \mathrm{~m}$ depth. The deepest section of the shown 


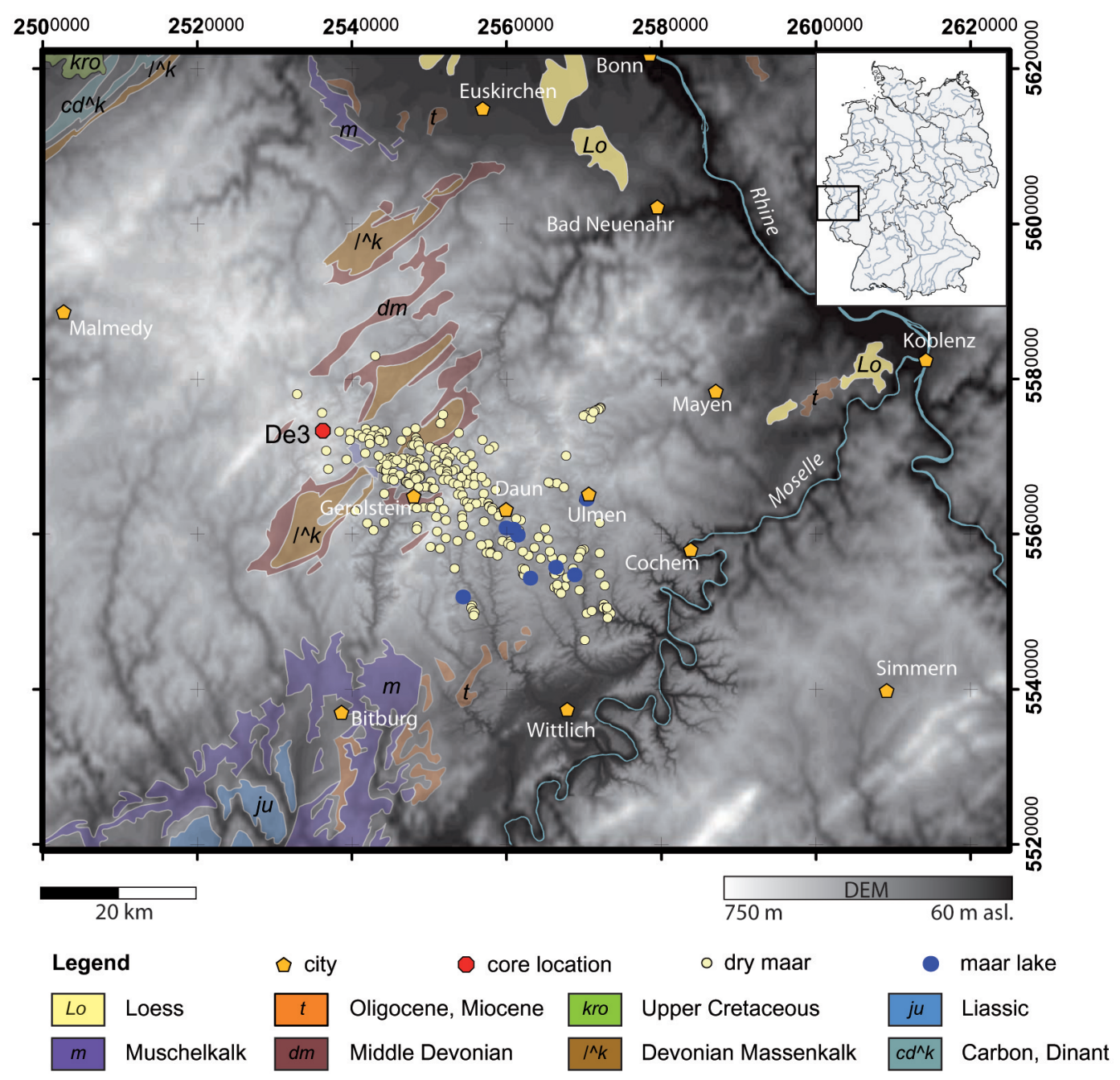

Fig. 1. Geological sketch map and elevation model of the Eifel region, including the calcerous rocks, such as the limestone bearing "Kalkmulden" in the Eifel N-S-zone, loess deposits and the locations of Maar lakes and dry maars after Büchel (1994). The map is based on the Geological Map of Germany 1:1 000000 (BGR 2002), GCS Deutsches Hauptdreiecksnetz, Gausszone 2, Bessel 1841. Locations of the sediment core De3 from the ELSA dust stack (see text) is marked with a red dot.

core is dominated by gyttja. Beginning in a depth of $38 \mathrm{~m}$ (36 ka BP) the content of homogeneous dust sediments increases rapidly and reaches the absolute maximum between 28-10 m depth, which represents the last glacial maximum. The organic content is very low during this period and increases once again with the Bølling transition $14 \mathrm{ka} \mathrm{BP}$ (Seelos et al., 2009).

\subsection{The RADIUS east wind module}

In the ELSA core De3 the content of dust and carbonates $(20-63 \mu \mathrm{m})$ carries information about the provenance of the windblown particles. Wind transported carbonates are detected in layers as single grains inside the dust sections with the same grain size as the non-carbonate dust components. Authigenic carbonate particles are not detected by the used algorithm. The authigenic carbonate production in the maar lakes during the observed dry and cold period is very low. To reconstruct information about the dominant wind directions for the Eifel region, we analyzed the ELSA core sequence De3 (Dehner Maar, Fig. 1) about the content of carbonates and loess.

The particle analysis method RADIUS (Rapid Particle Analysis of digital Images by ultra-high-resolution scanning of thin sections, Seelos and Sirocko, 2005) was developed to analyze and identify the different sediment structures in sediment cores, especially for cores of the ELSA project (Sirocko et al., 2005). The application allows the detection of climate controlled sedimentation processes like storm events under cool and dry conditions or fine laminated sequences during warm periods and spontaneous events like volcanic eruptions, slumps and turbidities (Seelos et al., 2009). The 


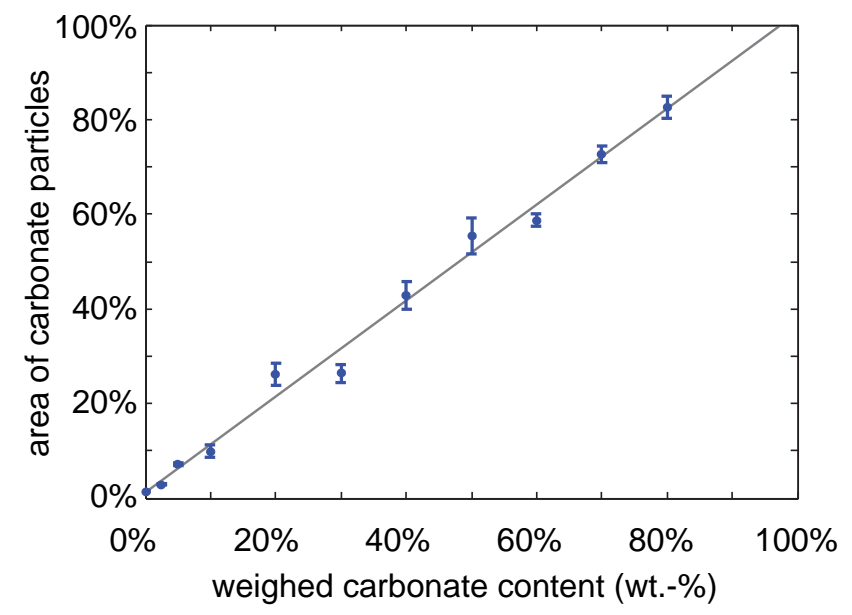

Fig. 2. Scatter plot of the weighted carbonate-quartz test samples versus the area percentage of detected carbonate particles. A calculated correlation coefficient $\left(R^{2}\right)$ of 0.94 shows the reliable detection and classification of carbonates by the RADIUS particle analysis system.

procedure is based on digital image analysis of single particles in a $200 \mu \mathrm{m}$ interval. Thus aggregates are separated into its single components. The lower detection limit is around $10 \mu \mathrm{m}$. The thin sections were scanned with 20x magnification under cross polarized light.

To analyze the paleo east wind layers, we developed a new software module, which uses the ELSA dust stack results and combines them with a carbonate detection algorithm. The carbonate tool is a self-contained software module of RADIUS, based on an adapted color detection algorithm to measure the content of carbonates.

By means of digital image analysis it is not possible to measure a percentage by weight but an area ratio. A calibration study is applied on twelve artificial samples with certain contents of carbonate particles (Fig. 2). The used carbonate particles consists of grinded Devonian limestone from the Eifel-N-S-zone. The loess material is taken from the core De2, a neighbor core of De3. The carbonate content of the loess is removed by cooking with hydrochloride acid. Different thin sections with a carbonate content of $0-80 \mathrm{wt} .-\%$, with finer increments in the range of a low carbonate content, are analyzed by application of the RADIUS method, using the same setting as for scanning the original samples. Different parts of the samples were scanned five times for an error estimation. The measured results of the areas content of the carbonate particles is plotted versus the weight percentage. The calculated correlation coefficient $R^{2}$ of 0.94 indicates the reliable classification of bright and carbonate particles.

The algorithm of the RADIUS east wind is applied using the same parameters for the whole core section and works in the following way (Fig. 3): In the first step the sediment is analyzed, wether a dust sequence is existing, which is defined as such if the probability of a dust event is higher than

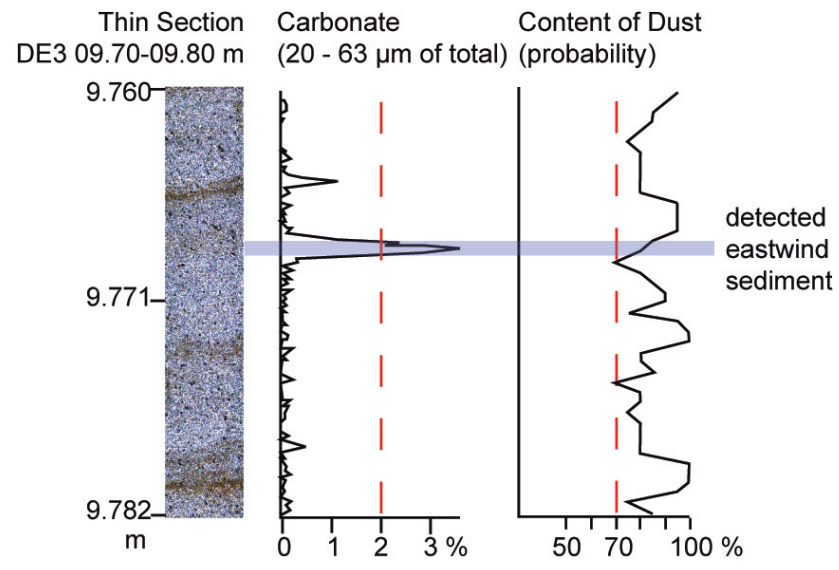

Fig. 3. Example of a dust sequence of core De3 showing a detected east wind layer (gray bar) during the late LGM with a silt sized carbonate content greater than $2 \%$ and a probability of dust greater than $70 \%$. The eolian transported carbonate particles of such layers are of the same mean size as the corresponding quartz grains.

$70 \%$. If the content of carbonates in the grain size class of 20-63 $\mu \mathrm{m}$ within such a detected dust sequence is higher than $1 \%$ we assume east winds. The wind crossed the carbonate basin and lime stone particles are looped up and subsequently deposited in the Dehner dry maar. This fixed combination of dust and carbonate detection results exclude misinterpretations in the case of authigenic carbonate productivity in the lake. If the climate situation changes to warm and wet conditions, the content of dust decreases at the same time and the wind detection algorithm is set to zero. The east wind frequency is calculated for fixed 100 years intervals by measuring the relationship between the thickness of carbonate containing layers (east wind layers) and layers below the threshold (west wind layers) in percent. The frequency analysis (100 year bins) depends on the continuous age depth model and all single $500 \mu \mathrm{m}$ segments that show east wind sediments are summed after the time correlation procedure. The RADIUS detection results are presented as 20 point arithmetic mean records.

\section{Results}

For the ELSA dust stack the Dehner Maar core sequence provides a high resolution reconstruction of east wind directions for Central Europe by provenance analyses. The measured ground noise signal for the content of authigenic carbonates over all core sequences is about $0.2 \%$. Two main modes according to wind speed and strength can influence deflating areas:

(i) transport of fine grained silty material $(<20 \mu \mathrm{m})$ at high altitude over very long distances,

(ii) transport of coarser material over short distances. 
Our results correspond to the second model of dust transport (Pye, 1987) as coarse silt material has been blown from the nearby river valleys as well as from the Devonian carbonate basins. We suggest that the relatively low content of carbonates in the silt fraction (max. $19.4 \%$ per sample) is produced by physical weathering in the carbonate belt. The measured grain sizes and shape parameters (elongation and form factor) of the eolian transported carbonate particles correspond to those of the quartz fraction.

The production of quartz particles in silt fraction by physical weathering processes (basically by frost shattering) are already described by Cilek (2001). Lab experiments show the effects of frost shattering on carbonate rocks produce carbonate granules (Lautridou and Ozouf, 1982). Secondary eolian processes such as deflation, saltation and corrasion are able to produce fine grained material like silt. This is in agreement with the generally low content of carbonate in our sequence.

Encouraged by the question about the sources and the transport distance of the carbonate particles we used electron microscopy to analyse one thick east wind layer (core De3, $9.773 \mathrm{~m}$ depth). A micrograph (Fig. 4) from a scanning electron microscope (Zeiss DSM 962) demonstrates the distribution of large carbonate particles in an east wind layer. Fig. 4a shows a carbonate particle with a diameter of about $55 \mu \mathrm{m}$ surrounded by quartz and feldspar minerals of the same size. The qualitative geochemistry analysis in Fig. 4b, measured in the center of the observed grain, shows the typical calcite pattern.

Regarding the whole record (Fig. 5), west winds are dominating the period $40.3-12.9 \mathrm{kaBP}$. The lowest content is about $0.2 \%$, representing the highest west wind activity during the period 24-22.5 $\mathrm{ka} \mathrm{BP}$. The maximum content of east wind formed sediments in a hundred years interval is $19.4 \%$ (32 ka BP).

The whole studied time period can be subdivided into three units:

(i) The first time period during MIS 3 (40.3-36 ka BP) is dominated by relative organic rich gyttja. Although $\mathrm{H} 4$ (39.4-37.2 ka BP) is the largest Heinrich event during the last glacial period (Hemming, 2004), in the Dehner dry maar the loess input is not increasing. However, the organic content in this period is really low. Thus, the analysis of carbonate bearing east wind layers is not possible for this time slice. The strong increase in dust accumulation starts quiet after the GIS-8.

(ii) When the global sea level began to fall even more ( $36 \mathrm{ka} \mathrm{BP}$ ) the climate passed into a colder and dryer state in middle Europe, which climaxed finally in the LGM (Clark et al., 2009). Thereupon, our data show that the content of east wind sediments increases. During this declining phase of MIS 3 (36-32 ka BP) thick east wind layers are accumulated (Fig. $5 \mathrm{D}$ ), but the frequency of east wind frequency is moderate. During the
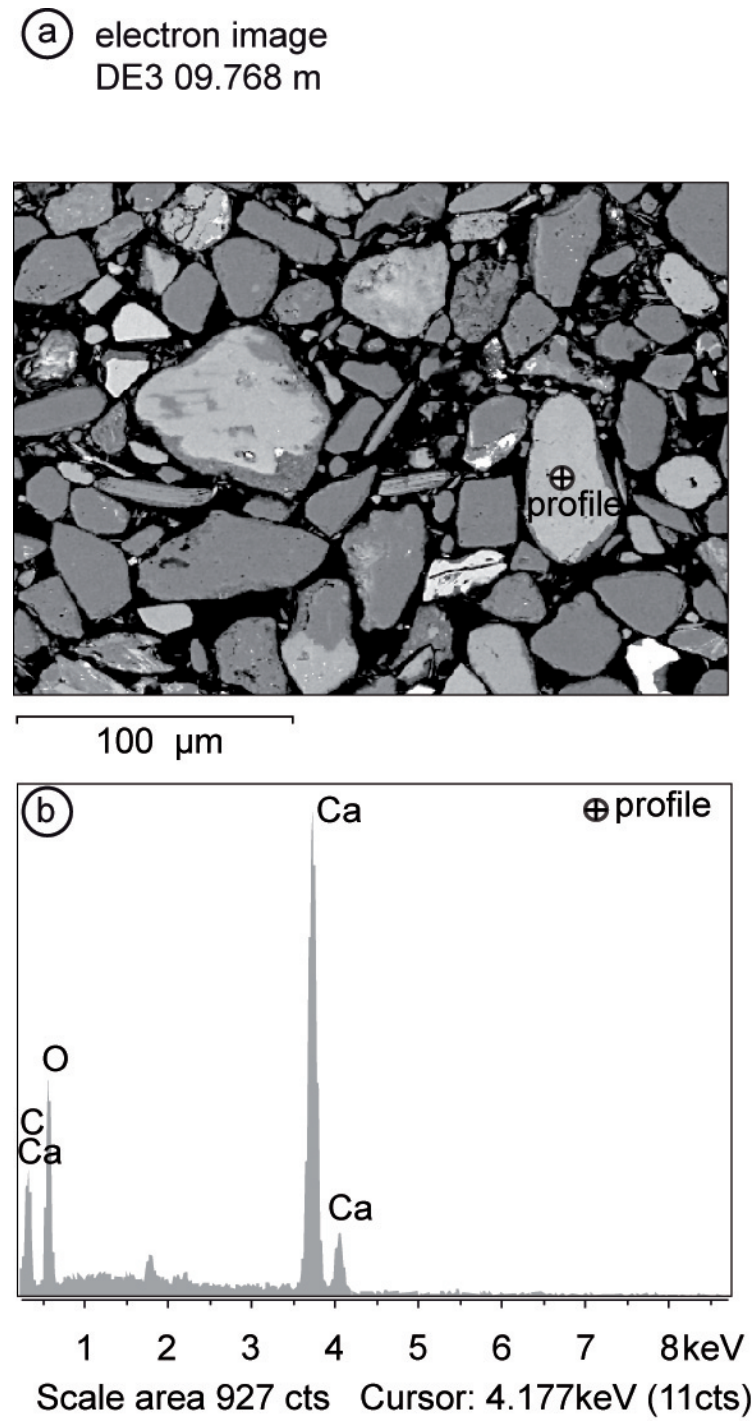

Fig. 4. (a) The electron image of a sample sequence of core DE3 (depth: $9.768 \mathrm{~m}$ ) shows the particle composition of an east wind layer. The sediment consists of well sorted quartz grains, carbonates and lithic components. The marked point in the center of a grain represents the geochemical profile shown in plot b. (b) The geochemical analysis (Zeiss DSM 962) of a large particle (a) shows a spectrum with pronounced carbonate bands. The ECD (equivalent circle diameter) of about ( $55 \mu \mathrm{m}$ is equal to the main part of particles in the sample sequence and typical for loess-like eolian sediments.

following period (32-24 ka) the content of dust sediments is always high (around 75\%), whereas the content of organics decreases to a very low level. The east wind frequency is relatively stable on a high level about $9 \%$ of east wind events per 100 years until the end of $\mathrm{H} 2$ equivalent. Maximum values occure during 32.5$30.5 \mathrm{ka} \mathrm{BP}$ (shortly before the $\mathrm{H} 3$ event), during $28.5-$ $27 \mathrm{kaBP}$ (corresponding with the time slice of GIS-4 and 3), and during 25-24.5 (H2 event). 
(iii) The period between $\mathrm{H} 2$ and the LGM is characterized by a major change in the climate system over Europe. The content of east wind transported sediments drop to a level of about $2 \%$. The number of east wind events per century decreases rapidly. During the late LGM (21-18 ka BP) and the subsequent Heinrich-1 event ( $16.6 \mathrm{ka} \mathrm{BP})$ the content of east wind sediments is once again noticeable high (mean value is around 6\% per century).

The domination of west winds, mainly influenced by westerlies, is also approved by our data. The continuous high resolution dust records of the ELSA dust detection allow very detailed analyses of east wind frequencies for the complete time period $40.3-12.9 \mathrm{ka} \mathrm{BP}$. One result of this study is a correlation of increased east wind frequency with extreme cold phases like Heinrich events or the maximum advance of the glacial ice sheets during the LGM.

\section{Discussion}

We suggest that the easterly wind proxy in the Dehner dry maar correspond to Heinrich events or extreme cold climate phases like the late LGM, when the 21 June-20 July insolation at $65^{\circ} \mathrm{N}$ rises again (Laskar et al., 2004; Berger and Loutre, 2002). During this time sea surface temperature (SST) records show minimum values, too (Lea et al., 2003).

Both, the Greenland Stadials (GS) before and after GS-4, which correspond to $\mathrm{H} 3$ in marine cores, are characterized by the highest number of east winds during MIS 2, the former one up to 160 identified east wind layers per century. However, the period representing the H3 itself has only a little amount of east wind sediments. It seems that the climate situation during $\mathrm{H} 3$ is in contrast with other Heinrich events (Gwiazda et al., 1996) and is coupled to relatively stable high-pressure systems over the east part of Europe.

In contrast to $\mathrm{H} 3, \mathrm{H} 2(24.8-23.2 \mathrm{ka} \mathrm{BP})$ is dominated by strong east winds, but the number of detected events per century drops to a value around 20. A comparison of two core sequences shows significant differences between the interstadial GIS-2 and the previous Heinrich-2 (Fig. 6).

H1 (16.6-15.2 ka BP), which is not recorded in the NGRIP micro particles, shows according to $\mathrm{H} 2$ a high amplitude in the record of east wind frequency. A higher east wind frequency is also modeled by Renssen et al. (2007) for the time slice of the late pleniglacial (18-15 ka BP).

$\mathrm{H} 4$ (39.4-37.2 ka BP) is known as the strongest Heinrich event. However, the analysis of the core De3 is not showing a similar dust signal to other European records like Nussloch (Antoine et al., 2009; Rousseau et al., 2007) but a distinctive minimum of the organic matter.

During MIS 2, the atmospheric conditions over middle Europe seems to be more stable and west winds dominate during the whole period (indicated by low content of wind transported carbonate particles). However, at about $24 \mathrm{ka} \mathrm{BP}$ after the beginning of the $\mathrm{H} 2$ event we recognize a major change in the climate system over Europe. The period of 21-18 ka (late LGM) is characterized by a lower east wind frequency than the Heinrich events $\mathrm{H} 2$ and $\mathrm{H} 1$. However, the time slice 20.5-19.5 ka BP shows numerous east wind events (about $12 \%$ per century). In addition our results show a slightly increased east wind frequency during the late LGM within the period between 24 and $17 \mathrm{kyr}$ BP. This is the time, when SST and insolation in the northern hemisphere reach minimum values. Climate simulations (Renssen et al., 2007) show a low east wind activity and increasing west winds for the LGM. These results could be supported by the data from De3, concerning the periode from 24-21 ka BP when east wind layers are less present.

The high resolution east wind frequencies of the Dehner dry maar allows a recognition of stadial-interstadial cyclicity. The correspondence between this record and other European sediment archives (Antoine et al., 2009) implies the existence of a link between the variations in the eolian dynamics over Western Europe and the atmospheric circulation over the North Atlantic area (Rousseau et al., 2007). The study of Antoine et al. (2009) compares possible centers of loess origin at the Upper Rhine Area (Germany) and interpret these results with the migration of the North Atlantic low. In general our east wind layers coincide with coarser sediment (high grain size index, GSI) in the Nussloch P4 loess profile. A higher GSI in the Rhine area is suggested as an enforced proximal eolian transport. We suggest the same mechanism for the Eifel region: Coarse carbonate grains are transported from sources in the direct neighborhood to the Dehner Maar sediment trap. Thus, the carbonate outcrops of the Eifel-North-South-Zone are the most possible source.

The most probable saisonality for dust entrainment is shown in the latest dust emission model for Europe by Sima et al. (2009). The authors suggest the maximum of dust emission from April to June. During HE the maximum activity is shifted by 1-2 month towards summer in comparison to GS and GIS states. During HE their model results show an increase of eastern wind directions, corresponding to the De3 data.

Since there is general blurriness in the used age-depthmodel, it is not possible to decide whether high easterly wind activity corresponds to the "beginning" or to the "end" of Heinrich events. Thus, we think that H1, H2 and LGM show a direct coupling to easterly wind systems. Renssen et al. (2007) and Isarin et al. (1998) demonstrated the important impact of slight N-S shifts of the belt of strong westerlies. Probably such shifts occurred concurrently with the numerous climatic oscillations that are recorded within the studied period 40-12 ka BP, which may have resulted in changing wind directions at the Eifel region.

Our continuous data show a high variability in changing wind directions. With this article we want to address the climate modeling community. Climate simulation might help 


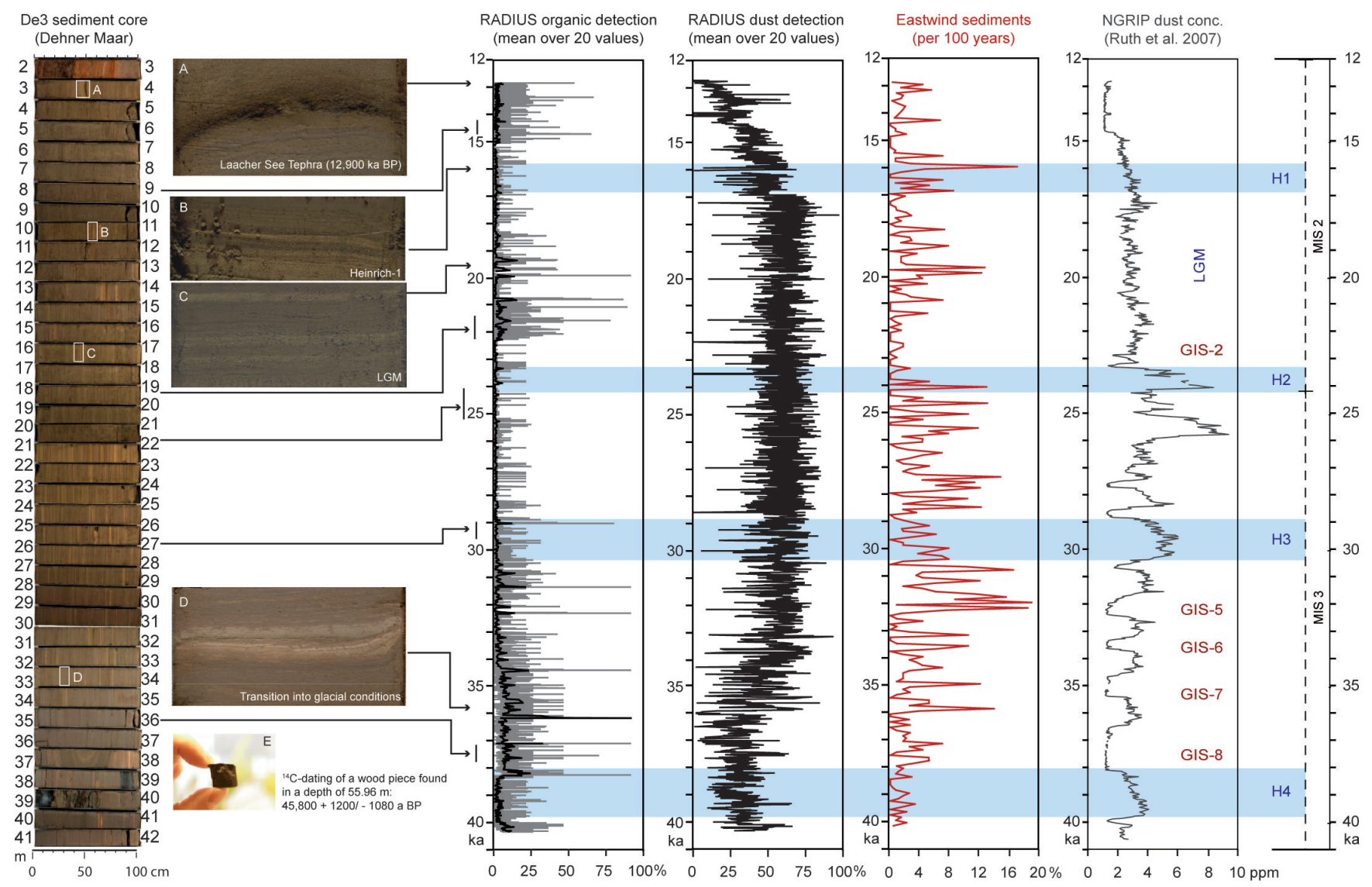

Fig. 5. Core sequence De3 40.3-12.8 ka BP (Dehner Maar): left: core images over the whole sequence (2-42 m); center-left: detailed sediment images: (A) Laacher See Tephra (LST, 12900 years BP), (B) Heinrich-1 equivalent layer, (C) example of a LGM layer, (D) transition into MIS-2, (E) ${ }^{14} \mathrm{C}$-dating of a piece of wood (spruce) found in a depth of $55.96 \mathrm{~m}(45.8+1.2 /-1.08 \mathrm{ka} \mathrm{BP})$; center-right: Radius detection records for the content of organics, Radius detection of dust (both with an original sampling resolution of $500 \mu \mathrm{m}$, Seelos et al. (2009)). Frequency of carbonate rich east wind sediments per 100 years (red). The comparison with the micro particles record (gray) from Greenland (Ruth et al., 2007) shows a common process of eolian dynamics linking North Atlantic and the European region. Blue bars: marking of Heinrich events (Hemming, 2004).

to answer the question what can possibly cause east winds during extreme cold climate conditions. Earlier results give some hints of atmospheric states.

Simulations of the LGM suggest that the glacial ice sheets had major effects on atmospheric circulation patterns. A glacial anticyclone, produced during summer months by high atmospheric pressure over the ice sheet, generated an easterly surface wind anomaly directly to the south of the ice sheet (Bartlein et al., 1998; COHMAP Members, 1988; Kutzbach and Wright, 1985). Some models show a permanent easterly flow south of the ice sheet (COHMAP Members, 1988; Kutzbach and Wright, 1985), but recent simulations show that easterly flow are less pronounced and more seasonally with a westerly flow returning in winter months (Whitlock et al., 2001; Bartlein et al., 1998). Evidence from eolian deposits in North America verify that the glacial anticyclone altered surface wind patterns and affected eolian systems during the LGM (Sweeney et al., 2004). Similar atmospheric processes are suggested for the European region, too. Katabatic and zonal winds controlled by the Weichselian Ice Sheet might be irrelevant: Dominating easterly wind directions only existed in areas being deglaciated or located immediately in front of the ice sheet during its maximum extension (Christiansen and Svensson, 1998; Renssen et al., 2007).

Atmospheric blocking as mentioned by Rimbu et al. $(2007,2008)$ is a large-scale, mid-latitude atmospheric phenomenon often associated with persistent quasi-stationary, synoptic-scale, high-pressure systems. The formation, maintenance and collapse of atmospheric blocking cause largescale circulation anomalies and strongly impact weather patterns. Such a situation can block the large-scale westerly flow over the northeast Atlantic and influence the wind direction over Europe.

The shutdown or reduction in strength of the North Atlantic meridional overturning allows the spread of winter sea ice across the North Atlantic, thus causing much colder 

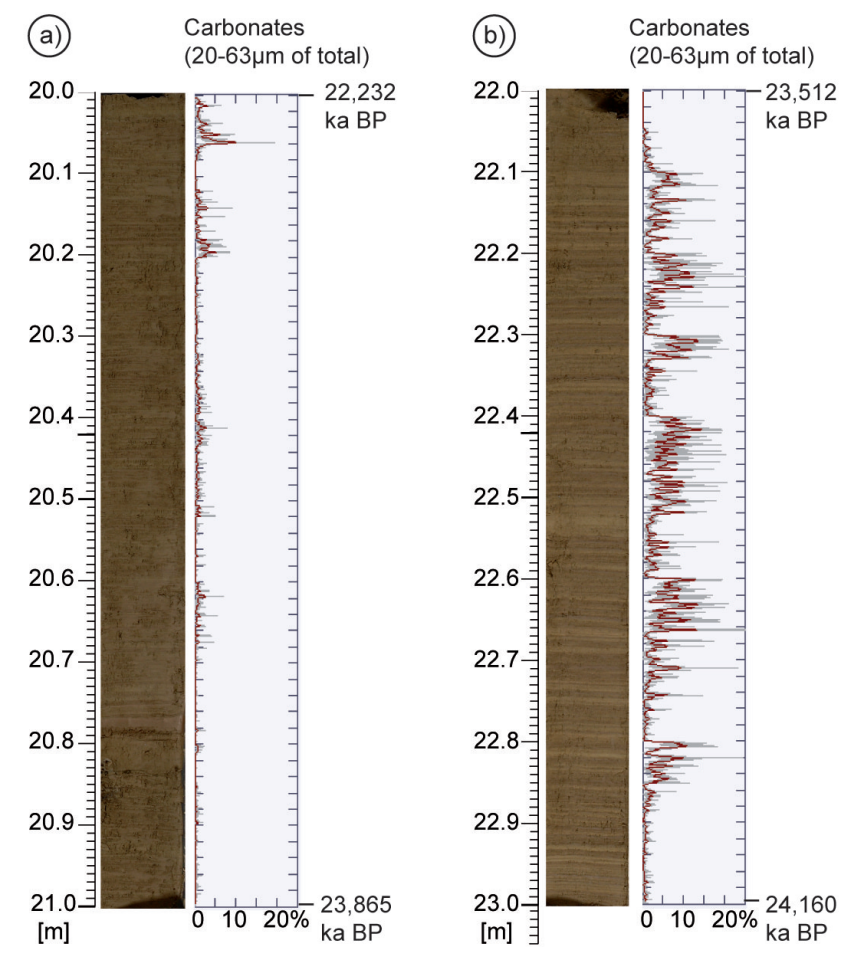

Fig. 6. The comparison of two sediment core sequences. De3 21-20 m (22 865-22 232 years BP) and De3 23-22 m (24 16023512 years BP) shows the variation of sediment structures for the periods of (a) the interstadial GIS-2 and (b) the previous Heinrich2. It is obvious, that the core sequence $23-22 \mathrm{~m}$ is characterized by coarse lamination in consequence of variable sediment composition. This alternation of carbonate rich and carbonate poor sections is caused by often changing wind directions.

winter from Greenland to Asia (Denton et al., 2005). A widespread sea ice cover might lead to a southward relocation of the polar front, the Icelandic Low as well as the westerlies. Subsequently, the strength of western winds in the Eifel region is reduced and east wind anomaly, probably by a glacial anticyclone, represents this weakening. This is what (Sweeney et al., 2004) suggested for the N-American continent, too. However, these explanations and especially its amplitude and the seasonality has to be checked within climate models. After Antoine et al. (2009) an ENE replacement of North Atlantic low pressure centers is leading to high GSI sediments at Nussloch. But this does not explain increasing detected east wind sediments in our data. Renssen et al. (2007) show in climate models that during the late pleniglacial northwestern winds are dominant because of direct response to an easterly relocation of the Icelandic low.

\section{Conclusions}

The high-resolution analysis of eolian transported sediments into the Dehner dry maar lead to the following conclusions:

1. The Dehner Dry maar is suitable to archive paleo east wind layers due to its location west of Devonian carbonate basins. Thus, eolian sediments with high carbonate content from the Dehner Maar (Eifel, Germany) can be interpreted as an east wind signal.

2. The problem remains to propose a regional atmospheric situation from a single sample location. However, Pfahl et al. (2009) have shown that the allocation of storm layers in maar lake sediments to recent regional meteorological data is statistically highly significant for at least the last decades. In addition, our results corresponding to other European dust proxies. Thus, we suggest that our results from the Dehner Maar are correspond to a regional atmospheric state.

3. The studied time period from 40.3-12.9 ka BP can be subdivided into three units: The first time period during MIS 3 (40.3-36 ka BP) is characterized by relative organic rich sediments of MIS 3. Thus, there is only little accumulation of dust in the Dehner dry maar and Heinrich 4 (39.4-37.2 ka BP) is not recorded in the archive by a dust proxy, but this period is dominated by an extreme low content of organic matter. The second time slice (36-24 ka BP) has an increased content of dust accumulation as well as of carbonate particles in comparison to the third unit. These results correspond with growth of the global ice sheets (Clark et al., 2009). The third unit (24-12.9 ka BP) is characterized by lower east winds sediments.

4. Increased east wind frequencies occur during the time intervals corresponding to the Heinrich events $\mathrm{H} 1$ and $\mathrm{H} 2$. Whereas the unusual $\mathrm{H} 3$ show no increased east wind frequency. The former and subsequent Greenland stadial intervals do so. Beside the east winds the dust sedimentation in Central Europe reaches maximum values during Heinrich events, too, which is suggested by Antoine et al. (2009) and Rousseau et al. (2007) for the Nussloch section (Germany).

5. The late LGM (21-18 ka BP) is characterized by a slightly elevated east wind frequency, which might be corresponding to solar forcing. The June insolation at $65^{\circ} \mathrm{N}$ is again increasing after minimum values in the time before (Laskar et al., 2004; Berger and Loutre, 2002).

6. This division into two atmospheric patterns is indicated by the micro particle-curve of the NGRIP ice core (Ruth et al., 2007), in which the pre-Heinrich-2 time slice is dominated by Dansgard/Oeschger like cycles, whereas 
the subsequent period shows a rather stable amount of dust concentrations. This significant change of atmospheric patterns might have been resulted in a change of wind directions near to the surface in middle Europe. To our knowledge this variability in atmospheric conditions for the European continent is first shown in this study.

Acknowledgements. The authors thank Pierre Antoine, an anonymous reviewer, Denis-Didier Rousseau, Jef Vandenberghe, and Urs Ruth, for their really constructive comments and Lothar Schütz and Konrad Kandler for the discussion. We would like to thank Klaus Schwibus and Günther Ritschel for sample preparation. This work is part of the first author's Phd thesis and funded by the German Science Foundation (DFG, Si594/21-2).

Edited by: D.-D. Rousseau

\section{References}

Antoine, P., Rousseau, D.-D., Moine, O., Kunesch, S., Hatté, C., Lang, A., Tissoux, H., and Zöller, L.: Rapid and cyclic eolian deposition during the Last Glacial in European loess: a high-resolution record from Nussloch, Germany, Quaternary Sci. Rev., 28 (25-26), 2955-2973, doi:10.1016/j.quascirev.2009.08.001, 2009.

Bartlein, P., Anderson, K., Anderson, P., Edwards, M., Mock, C., Thompson, R., Webb, R., Webb III, T., and Whitlock, C.: Paleoclimate simulations for North America over the past 21,000 years: features of the simulated climate and comparisons with paleoenvironmental data, Quaternary Sci. Rev., 17, 549-586, 1998.

Berger, A. and Loutre, M. F.: An exceptionally long interglacial ahead?, Science, 297, 1287-1288, 2002.

Brauer, A., Haug, G. H., Dulski, P., Sigman, D. M., and Negendank, J. F. W.: An abrupt wind shift in western Europe at the onset of the Younger Dryas cold period, Nat. Geosci., 1, 520523, doi:10.1038/ngeo263, 2008.

Büchel, G.: Vulkanologische Karte West-und Hocheifel, Landesvermessungsamt Rheinland-Pfalz, 1994.

Christiansen, H. H.: Windpolished boulders and bedrock in the Scottish Highlands: evidence and implications of Late Devensian wind activity, Boreas, 33, 82-94, doi:10.1080/03009480310006998, 2004.

Christiansen, H. H. and Svensson, H.: Windpolished boulders as indicators of a Late Weichselian wind regime in Denmark in relation to neighbouring areas, Permafrost Periglac., 9, 1-21, doi:10.1002/(SICI)1099-1530(199801/03)9:1<1::AIDPPP271>3.0.CO;2-X, 1998.

Cilek, V.: The loess deposits of the Bohemian Massif: silt provenance, palaeometeorology and loessification processes. Quatern. Int., 76-77, 123-128, doi:10.1016/S1040-6182(00)00096-3, 2001

Clark U. C., Dyke, A. S., Shakun, J. D., Carlson, A. E., Clark, J., Wohlfarth, B., Mitrovika, J. X., Hostetler, S. W., McCabe, A. M.: The last glacial maximum, Science, 325, 710-714, 2009.
COHMAP Members: Climatic changes of the last 18000 years: observations and model simulations, Science, 241, 1043-1052, 1988.

Denton, G. H., Alley, R. B., Comer, G. C., and Broecker, W. S.: The role of seasonality in abrupt climate change, Quaternary Sci. Rev., 24, 1159-1182, 2005.

Godzik, J.: Sedimentological record of eolian processes from the Upper Plenivistulian and the turn of Pleni- and Late Vistulian in Central Poland, Z. Geomorphol., Supplement-Band, 90, 51-60, 1991.

Gwiazda, R. H., Hemming, S. R., and Broecker, W. S.: Provenance of icebergs during Heinrich event 3 and the contrast to their sources during other Heinrich episodes, Paleoceanography, 11, 371-378, 1996.

Hatté, C., Fontugne, M., Rousseau, D.-D., Antoine, A., Zöller L., Laborde, N.T., Bentaleb, I.: $\delta^{13} \mathrm{C}$ variations of loess organic matter as a record of the vegetation response to climatic changes during the Weichselian, Geology, 26(7), 583-586, doi:10.1130/0091-7613(1998)026<0583:CVOLOM > 2.3.CO;2, 1998.

Hemming, S. R.: Heinrich events: Massive late Pleistocene detritus layers of the North Atlantic and their global climate imprint, Rev. Geophys., 42, RG1005, doi:10.1029/2003RG000128, 2004.

Hostetler, S. W., Clark, P. U., Bartlein, P. J., Mix, A. C., and Pisias, N. J.: Atmospheric transmission of north Atlantic Heinrich events, J. Geophys. Res.-Atmos., 104(D4), 3947-3952, doi:10.1029/1998JD200067, 1999.

Huijzer, B. and Vandenberghe, J.: Climatic reconstruction of the Weichselian Pleniglacial in north western and central Europe, J. Quaternary Sci., 13, 391-417, 1998.

Isarin, R. F., Renssen, H., and Koster, E. A.: Surface wind climate during the Younger Dryas in Europe as inferred from eolian records and model simulations, Palaeogeogr. Palaeoclimatol. Palaeoecol., 134, 127-148, 1997.

Isarin, R.F.B, Renssen, H. and Vandenberghe, J.: The impact of the North Atlantic Ocean on the Younger Dryas climate in northwestern and central Europe, J. Quaternary Sci., 13(5), 447-453, doi:10.1002/(SICI)1099-1417(1998090)13:5<447::AIDJQS402>3.0.CO;2-B, 1998.

Krook, L.: Heavy minerals in the Belvédère deposits, Meded. Rijks Geol. Dienst, 47, 25-30, 1993.

Kutzbach, J. and Wright, H.: Simulation of the climate of 18000 years BP: results for the North American, North Atlantic, European sector and comparison with the geological records of North America, Quaternary Sci. Rev., 4, 147-187, 1985.

Laskar,J., Robutel, P., Joutel, F., Gastineau, M., Correia, A.C.M., Levrard, B.: A long-term numerical solution for the insolation quantities of the Earth, Astron. Astrophys., 428(1), 261-285, doi:10.1051/0004-6361:20041335, 2004.

Lautridou, J. P. and Ozouf, J. C.: Experimental frost shattering. 15 years of research at the Centre de Géomorphologie du CNRS. Prog. Phys. Geog., 6, 215-232, doi:10.1177/030913338200600202, 1982.

Lea, D. W., Pak, D. K., Peterson, L. C., and Hughen, K. A.: Synchroneity of Tropical and High-Latitude Atlantic Temperatures over the Last Glacial Termination, Science, 131(5), 1361-1364, doi:10.1126/science.1088470, 2003. 
NorthGRIP Members: High-resolution record of Northern Hemisphere climate extending into the last interglacial period, Nature, 431, 147-151, 2004.

Pfahl, S., Sirocko, F., Seelos, K., Dietrich, S., Walter, A., and Wernli, H.: A new windstorm proxy from lake sediments - a comparison of geological and meteorological data from western Germany for the period 1965-2001, J. Geophys. Res., 114, D18106, doi:10.1029/2008JD011643, 2009.

Pye, K.: Aeolian dust and dust deposits, Academic Press, London, 1987.

Renssen, H., Kasse, C., Vandenberghe, J., and Lorenz, S. J.: Weichselian Late Pleniglacial surface winds over northwest and central Europe: a model-data comparison, J. Quaternary Sci., 22, 281293, 2007.

Rimbu, N., Lohmann, G., and Grosfeld, K.: Northern Hemisphere atmospheric blocking in ice core accumulation records from northern Greenland, Geophys. Res. Lett., 34, 9704, doi:10.1029/2006GL029175, 2007.

Rimbu, N., Lohmann, G., and Grosfeld, K.: Northern Hemisphere atmospheric blocking in ice core accumulation records from northern Greenland, PAGES News, 16, 5-7, 2008.

Rousseau, D.-D., Sima, A., Antoine, P., Hatté, C., Lang, A., and Zöller, L.: Link between European and North Atlantic abrupt climate changes over the last glaciation, Geophys. Res. Lett., 34, L22713, doi:10.1029/2007GL031716, 2007.

Ruth, U., Bigler, M., Röthlisberger, R., Siggaard-Andersen, M., Kipfstuhl, S., Goto-Azuma, K., Hansson, M., Johnsen, S., Lu, H., and Steffensen, J.: Ice core evidence for a very tight link between North Atlantic and east Asian glacial climate, Geophys. Res. Lett., 34, L03706, doi:10.1029/2006GL027876, 2007.

Schwan, J.: The structure and genesis of Weichselian to Early Holocene eolian sand sheets in western Europe, Sediment. Geol., 55, 197-232, 1988.

Seelos, K. and Sirocko, F.: RADIUS-rapid particle analysis of digital images by ultra-high-resolution scanning of thin sections, Sedimentology, 52, 669-681, 2005.

Seelos, K., Sirocko, F., and Dietrich, S.: A continuous high resolution dust record for the reconstruction of wind systems in Central Europe (Eifel, Western Germany) over the last $133 \mathrm{ka}$, Geophys. Res. Lett., doi:10.1029/2009GL039716, 2009.
Sima, A., Rousseau, D.-D., Kageyama, M., Ramstein, G., Schulz, M., Balkanski, Y., Antoine, P., Dulac, F., and Hatté, C.: Imprint of North-Atlantic abrupt climate changes on western European loess deposits as viewed in a dust emission model, Quaternary Sci. Rev., 28(25-26), 2851-2866, doi:10.1016/j.quascirev.2009.07.016, 2009.

Sirocko, F., Seelos, K., Schaber, K., Rein, B., Dreher, F., Diehl, M., Lehne, R., Jäger, K., Krbetschek, M., and Degering, D.: A late Eemian aridity pulse in central Europe during the last glacial inception, Nature, 436, 833-836, 2005.

Sweeney, M., Busacca, A., Richardson, C., Blinnikov, M., and McDonald, E.: Glacial anticyclone recorded in Palouse loess of northwestern United States, Geology, 32, 705-708, 2004.

van den Bogaard, P.: 40Ar/39Ar ages of sanidine phenocrysts from Laacher See Tephra (12,900 yr BP): Chronostratigraphic and petrological significance, Earth Planet. Sci. Lett., 133, 163-174, 1995.

van Huissteden, J., Schwan, J. C. G., and Bateman, M. D.: Environmental conditions and paleowind directions at the end of the Weichselian Late Pleniglacial recorded in eolian sediments and geomorphology (Twente, Eastern Netherlands), Geol. Mijnbouw, 80, 1-18, 2001.

Vandenberghe, J.: Changing conditions of eolian sand deposition during the last deglaciation period, Z. Geomorphol., Neue Folge, Supplement, 90, 193-207, 1991.

Vandenberghe, J., Isarin, R. F. B., and Renssen, H.: Comments on windpolished boulders as indicators of a Late Weichselian wind regime in Denmark in relation to neighbouring areas by Christiansen and Svensson (9(1), 1-21, 1998), Permafrost Periglac., 10, 199-201, 1999.

Whitlock, C., Bartlein, P., Markgraf, V., and Ashworth, A.: The midlatitudes of North and South America during the Last Glacial Maximum and early Holocene: Similar paleoclimatic sequences despite differing large-scale controls, Interhemispheric Climate Linkages: Present and Past Interhemispheric Climate Linkages in the Americas and their Societal Effects, Academic Press, New York, NY, 391-416, 2001. 